\title{
THE LOMCE WILL EVICT THE CLASSES
}

\section{LA LOMCE DESAHUCIARÁ LAS CLASES}

María Barrios Carles and Miriam Godoy Millán. University of Granada

Artículo dirigido por: Katia Caballero. Departamento de Didáctica y Organización Escolar. Universidad de Granada

Fecha de recepción: 31 de enero de 2014.

Fecha de revisión: 19 de marzo de 2014.

Fecha de aceptación: 11 de abril de 2014.

\section{ABSTRACT}

This article develops an analysis of the scholarly failure that will bring the new Education Law, called LOMCE. It will focus on the underlying outcomes of the proposals that it makes. It will also try to explain from the social perspective the consequences that this new law will have on students, not only paying attention to the academic field. A historical review can make us realise how we got to the current situation and make us anticipate the success or failure of this law.

\section{KEY WORDS}

School segregation, Academic failure, Evaluation, Quality.

\section{RESUMEN}

Este artículo desarrolla un análisis del fracaso escolar que desencadenará la nueva Ley de Educación, Ilamada LOMCE. Se centrará en los resultados subyacentes de las propuestas que hace. También intenta explicar desde una perspectiva social las consecuencias que esta nueva ley tendrá en los alumnos, no solo prestando atención al campo académico. Una revisión histórica puede hacer darnos cuenta de cómo hemos llegado a la situación actual y que nos anticipemos a predecir el éxito o fracaso de esta ley.

\section{PALABRAS CLAVE}

Segregación escolar, Fracaso escolar, Evaluación, Calidad.

The future LOMCE will be a reactionary law which will deepen scholarly failure. Why do we make this strong accusation?

The majority of the modifications in LOMCE do not take into account one of the most important aspects for quality education: comprehensiveness. According to Díez Gutiérrez (2013), "comprehensiveness concerns an education in which students receive a strong core of common contents and the same basic experiences of learning as long as possible, or at least, during Mandatory Secondary Education, in the same institutions and in common and shared classrooms. This avoids the segregation of students in different ways of teaching which can be irreversible. With comprehensive education, aspirations of equal opportunities are condensed", which means that the 
main goal is that all students receive a more equitable education based on the right to diversity in the same school and "that we learn from early ages not to leave anybody behind".

According to Gimeno and Rodríguez (2013: 34) and Díez Gutiérrez (2013), the majority of countries who obtain better results in the PISA evaluation, are also those who extend this common teaching for 9 or 10 years. This means that countries in which comprehensiveness reaches until 16 years old obtain better results than those who segregate them at early ages. The segregation of students with worse results is translated in a teaching of lower quality. In addition, basic subjects for the integral training of people are removed, making a distinction between students one year before, as LOMCE establishes. This recalls us to the Educational System previous to the LGE of 1970 .

As mentioned before, this law advances the age in which students must choose between a professional way and an academic way. The academic way will be the 4 fourth grade of ESO and the professional way will be Basic Vocational Training.

This segregation in a time in which students are not mature enough to make the best choice, will cause the students with families with lower salaries to choose the professional way and, as a consequence, see themselves as less qualified than the rest. Moreover, as the collective "Soy Pública" (2013: 3) states, "the difference between 4 fourth grade of ESO and Basic Vocational Training will be some subjects in the same school, which can be proved in the text of the LOMCE, which is called into question the formative purpose of BVT".

As affirmed Gimeno and Rodríguez (2013: 9) "it is intended to convert Vocational Training in a dead way, repeating, this way, the error of the LOGSE, and there are mechanisms that threaten with moving forward the segregation to the second grade", which can worsen the situation even more. "In addition, there is evidence that Basic Vocational Training will have less vacancy each time and will probably be for a fee".

Summing up, when students finish Mandatory Secondary Education, they are already labelled depending on the way they have chosen, what constitutes a discrimination. If they have studied 4 fourth grade of ESO they will obtain a title of more status (School Graduate) than those who have studied Basic Vocational Training, who do not obtain it. Besides, those students who study the academic way do not have to pass special tests to access Higher Secondary Education, as opposed to those students who study the professional way (this can be seen in the Art. 20.2 of LOMCE). "This is a sign that in Mandatory Education the knowledge applied is less valued". (Gimeno and Rodríguez, 2013: 62).

A new measure that LOMCE establishes is the introduction of exams at the end of some stages or reválidas. There will be one reválida at the end of Primary Education (it will not have eliminatory character), and two more, one at the end of Mandatory Secondary Education to obtain the School Graduate and another at the end of Higher Secondary Education, which replaces the current University Entrance Exam. According to Bolívar (2013: 12), these last two reválidas will have eliminatory character in order to 
"discriminate good students from bad students, to segregate ones from others, against what comprehensive education intended. And this is the way to understand that the Minister affirmed that "the University Entrance Exam does not work because $94 \%$ of students pass it", that is why it must be abolished and establish, in its place, another proof of reválida of Higher Secondary Education.

"Quality must be always for some students, not for all." That is why the Minister Wert must think about the improvement of the forms of evaluation in education. According to Gimeno and Rodríguez (2013: 10), by contrast, "the evaluation must have a clear formative purpose, of knowledge and support to the processes of learning and personal development. An exclusive evaluation, which penalises and controls based on frequent and standardised testing, is opposite to its educative sense and to human diversity, generating school-leaving and exclusion." There is not a perfect pattern of evaluation, but we are sure about some aspects of it, like evaluation should not only be based on final results, but on the continuous process and development of each child, attending to his/her characteristics and situations. Therefore, we are against reválidas, which only focus on the result of an exam. They have no other purpose than establishing obstacles for students which may have had a bad result in the exam but their progress is positive, leading to school failure.

Furthermore, according to Gimeno and Rodríguez (2013: 41-42), the results of these tests are published and this causes competitiveness among schools and, as a consequence, social segregation. The election of the schools made by parents will be mediated through the rankings established by external evaluations (all parents will want their children to go the school with the best results) and the possibilities of specialization will mean a competition among schools and the creation of schools of different categories, when there should be cooperation among them. Students with a lower economic status will receive a worse quality of education due to a lack of resources. In addition, there will be competition not only among schools, but also among students within the same school. Thereby, the school will favour a survival atmosphere which will not promote a good teaching and learning process.

Regarding the methodology and the curriculum, in agreement with Gimeno and Rodríguez (2013: 30), the LOMCE returns to the traditional, more centralized pedagogy, with external evaluations that determine what to teach and an increase in the percentage of imposed contents. Good practices and innovative experiences of other countries which mean pedagogic autonomy and flexibilization of the curriculum are useless according to the political interests of the right wing party. Another aspect which affects this restricted view of the curriculum is that the Religion subject becomes more important and evaluable again. It is included inside the compulsory subjects in every grade of Primary Education. Parents can choose between Religion or Cultural and Social Values for their children. The increase of the subject of Religion can be due to the indoctrination that all governments want. They pretend to create a set of values and attitudes to implement among students according to political ideals. Besides, the contents of the subject Cultural and Social Values (alternative to Religion) will be treated from a subjective point of view established by the right wing party. In fact, the difference between these two subjects is not very remarkable, what makes students choose the subject of Religion because they generally will obtain better marks. 


\section{CONCLUSIONS}

Why will LOMCE be a reactionary law?

Its main characteristics are segregation at an early age; increase of selection exams; organization of the ways in Mandatory Secondary Education with an important reduction of resources, which worsen the quality of education; a restricted methodology; pathways marked by the social condition of students; creation of Basic Vocational Training (another pathway) which will be the exit of a lot of students. In addition, LOMCE converts the right to education in a benefit, which one can have or not. A reduced group of students will be the only privilege to success academically, while the others will be condemned to scholarly failure. In the end, the LOMCE, has achieved its manipulative purpose: the ideological control of future citizens (Gimeno and Rodríguez, 2013).

\section{REFERENCES}

- Asociación "Soy Pública” (2013). Anteproyecto de la LOMCE analizado.

- Bernal Agudo, J.L. y Lorenzo Lacruz, J.(2013). Privatization of public education. A trend in Spain. A way towards inequality. Revista Profesorado, 16, 103-131.

- Bolívar A. y Uruñuela P. (2013). La LOMCE, la reforma que viene. Revista digital del Fórum Europeo de Administradores de la Educación de Aragón, 7, 930.

- Bolívar, A. (2012). Hastiados de reformas educativas. Revista Escuela.

- Bolívar, A. (2013). Volver a políticas educativas fracasadas. Revista Escuela, 277, 37.

- Bolívar, A. y San Fabián, J. L. (2013). La LOMCE, ¿una nueva ley para mejorar la calidad educativa? Artículo de actualidad, 1, 7-11.

- Colectivo Lorenzo Luzuriaga. (2012). Documento sobre la LOMCE: Diez preguntas para el ministro Wert.

- Díez Gutiérrez, E. J. (2013). Entrevista a Enrique Javier Díez Gutiérrez sobre la LOMCE de la Wertgüenza (IV). Obtenido el 9/05/2013 de: http://lomceno.wordpress.com/2013/04/05/entrevista-a-enrique-javier-diezgutierrez-sobre-la-lomce-de-la-wertguenza-iv/

- Gimeno \& Rodríguez, J. and others (2013). Por otra política educativa. Sevilla: Ediciones Morata.

- Ley Orgánica 8/2013, de 9 de diciembre, para la Mejora de la Calidad Educativa. (BOE n² 295, 10-12-2013). 